\title{
Qualitative Research on Educational Technology: Philosophies, Methods and Challenges
}

\author{
Heng Luo \\ School of Education, Syracuse University \\ 330 Huntington Hall, Syracuse University, Syracuse, New York 13244, United States \\ E-mail: heluo@syr.edu
}

Received: August 9, 2011 Accepted: November 1, 2011 Published: November 15, 2011

doi:10.5296/ije.v3i2.857ＵRL: http://dx.doi.org/10.5296/ije.v3i2.857

\begin{abstract}
This paper reviews qualitative research in the field of educational technology through the lens of ontology, epistemology and methodology. A definition of educational technology research is followed by a discussion on how basic research in this field fails to render progress in academic achievement and the potential of qualitative inquiry to promote learning and teaching. Different ontological and epistemological assumptions behind such two research methodologies are also summarized and discussed. The paper then identifies three qualitative research methods that are prevalent in the field of educational technology: ethnography, case study and design-based research. The characteristics, strengths and limitations of those three methods are analyzed using examples from the literature within the past three decades.
\end{abstract}

Keywords: Educational technology, Qualitative research, Ontology, Epistemology, Ethnography, Case study, Design-based research 


\section{The definition of educational technology research and its problems}

Educational technology research, as defined by Januszewski and Molenda (2008), refers to the study of "facilitating learning and improving performance by creating, using, and managing appropriate technological processes and resources” (p. 1). Process in the definition refers to a series of activities that lead to a specified result. Such activities include those of using or managing the resources for education, as well as those of designing and creating them. Resources often refer to the high-tech tools such as digital media, computer software, or learning systems that are designed or used for educational purposes. However, the broader definition of resources can also include people, community, and policy, etc.

The advancement of educational technologies, especially computer technologies has brought significant changes in our educational systems, with computers playing a more and more important role in teaching and learning. According to a recent report published by the U.S. Department of Education (Gray, Thomas \& Lewis, 2010), for all public schools in fall 2008, 97 percent had one or more instructional computers located in classrooms and 58 percent of schools had laptops on carts. The ratio of students to instructional computers with Internet access was 3.1 to 1 . Technology devices other than computer were also widely used for instruction, the percentage of schools that provided such devices are: DLP and LCD projectors (97\%), video conferencing unit (22\%), interactive whiteboard (73\%), classroom response systems (38\%), and digital cameras (93\%). From teaching machines to personal computers, from E-mail to Web 2.0, from audio-visual aids to interactive multimedia, the emergence of new technologies with its increased availability and upgraded functionalities has raised people's expectation that great advances and improvements in learning and instruction would occur along with the progress of technologies (Spector, 2001).

Such expectation is yet to be met. Apart from the initial excitement about the computers or internet and the proliferation of research studies about their use in education, students' academic achievement in the past 30 years has seen little progress. According to the National Center for Education Statistics (2010), the average reading and mathematics scores for American 17-year-olds in 2008 were not significantly different from the scores in the early 1970s. Such finding can be rather heart-sinking considering that most schools didn't even have a computer in the early 1970s. As the statistically significant findings from many published educational technology research fail to really promote learning and teaching, more and more researchers started to question the nature of such research. For example, Robert Ebel (1967), the past president of the American Educational Research Association (AERA), questioned the value of basic research in education with the following argument:

The process of education is not a natural phenomenon of the kind that has sometimes rewarded scientific investigation. It is not one of the givens in our universe. It is manmade, designed to serve our needs. It is not governed by any natural laws. It is not in need of research to find out how it works. It is in need of creative invention to make it work better. (p.81)

Cronbach (1975) agreed with Ebel, and raised his concern that empirical research in education might be doomed to fail since researchers simply cannot produce generalizations 
fast enough to adapt the instructional treatments to the myriad of variables inherent in any given context of instruction. Such concern was echoed by Ross, Morrison and Lowther (2010) three decades later, who pointed out that many research studies on "cutting-edge" technologies only focused on proving the "effectiveness" of technology, while failed to address the more important issues such as "in what ways, in which contexts, for whom, and why” (p. 31) technology facilitates learning. They argued that relevant and quality research on educational technology must do more than simply presenting the empirical findings on how well a technology application worked, but should also be able to interpret why it worked. Some researchers attribute the problems in educational technology research to the philosophical assumption behind how science is defined in the field. As Reeves (1995) pointed out,

Most of the research in instructional technology is grounded in a "realist" philosophy of science, i.e., conducted under the assumption that education is part of an objective reality governed by natural laws and therefore can be studied in a manner similar to other natural sciences such as chemistry and biology. If this assumption about the nature of the phenomena we study is erroneous (and I believe it is), then we inevitably ask the wrong questions in our research. (p.461)

To address such problem, this study first provides a comparative analysis of four major philosophical assumptions behind educational technology research through the lens of ontology and epistemology, and then selects three qualitative research methods that are prevalent in the field of educational technology for further analysis using examples from the literature within the past three decades to demonstrate their characteristics, strengths, limitations and unique contributions of knowledge.

\section{Philosophical Assumptions behind Educational Technology Research}

Philosophical assumptions with regard to epistemology and ontology are believed to influence the instructional strategies and methods (Duffy \& Jonassen, 1992), thus also have a great impact on the research of studying them. Four major philosophical perspectives can be identified from the literature of educational technology research and will be discussed in this section. Those philosophical perspectives are: objectivism and realism, idealism and rationalism, relativism, and pragmatism.

\subsection{Objectivism and Realism}

Objectivism and realism view the world as real and such reality exists in independence of any human conception or understanding (Bednar et al., 1995; Lakoff, 1987; Mackay, 1997; Reber, 1995). Unlike realism that simply assumes the existence of reality; the ontological view for objectivism further specifies the nature of such existence in terms of properties and relations between its entities. As Lakoff (1987) described, "all reality consists of entities, which have fixed properties and relations holding among them at any instant” (p.160). Derived from such ontology, objectivists view learning as recreating a correct representation that mirrors the external world in human mind. Basic research studying the "effect" of an technology application are rooted in the objectivist or realist epistemology, measuring the effectiveness 
of treatment in terms of students' mastery of “knowledge”, which is a series of pre-specified behaviors (e.g. recalling facts, giving the right answer, getting certain score).

\subsection{Idealism and Rationalism}

Idealism and rationalism originated from the same philosophical perspective that doesn't view the world as the absolute physical existence but defines reality as mental representations which cannot be separated from the mind (Lombardo, 1987; Reber, 1995). Idealists like Kant embrace the ontology that mind shapes the world as we perceive it, and the "ideas" are the only things which can be directly known for certain (Yolanda, 1998). Rationalism discusses the epistemological aspect of the idealistic philosophy, emphasizing the power of reasoning over sensing when understanding the world; as "the criterion of the truth is not sensory but intellectual and deductive" (Bourk, 1962, p.263). Idealism and rationalism shift the focus of educational technology research from examining the change of students' behavior to the change of students' way of thinking. For example, computers are considered as cognitive tools that reorganize the mental structures of a learner making sense of the world (Jonassen, 1996).

\subsection{Relativism}

Relativism is the umbrella term for philosophical perspectives that oppose the notion of absolute truth or reality, and consider truth and reality as socially, culturally and experientially constructed, local and specific to the observer and the context (Guba and Lincoln, 1983). Relativism constructs meanings of experiential or physical events within the relationship between them and believes that meaning cannot exist independently with of other events (Reber, 1995). Research studies built upon the relativist epistemology are usually conducted in a natural setting, without efforts to control extraneous variables. They often involve rich descriptions of the context, learner behaviors and opinions. Its emphasis on learners' experience and voice allows learners to construct their own reality regarding the use of technology in learning. Research studies of this kind are often categorized as qualitative research because of the extensive use of ethnographic data and qualitative analysis method.

\subsection{Pragmatism}

Pragmatism originated in the United States around 1870 as a "method for settling metaphysical disputes that might otherwise be interminable” (James, 1995: 1907, p.28). Pragmatism rejects the notion of absolute dualism such as objectivism vs. subjectivism, or rationalism vs. empiricism; and "prefers more moderate and commonsense versions of philosophical dualisms based on how well they work in solving problems" (Johnson \& Onwuegbuzie, 2004, p.18). Pragmatism endorses fallibilism and views truth as contemporary, ever-changing and a matter of degree (James, 1995:1907). Since research conclusions will never be viewed as perfect and absolute, pragmatists argued that the purpose of research inquiry was simply to "fix" situation, or as phrased by John Dewey, "the controlled or directed transformation of an indeterminate situation into one that is so determinate in its constituent distinctions and relations” (Dewey, 1999, p.171). The philosophical and methodological middle ground offered by pragmatism offers researchers a third choice 
besides basic research and ethnography, which draws upon the strength of both quantitative and qualitative methods to address certain research questions. However, conducting mixed method research is often more expensive and time consuming, and places higher demand on researchers' skill sets.

The ontological and epistemological assumptions of the four philosophical perspectives discussed above are summarized in Table 1, with their implication for educational research.

Table 1. Ontology, Epistemology and Research Implications of the Four Philosophical Perspectives

\begin{tabular}{|c|c|c|c|}
\hline $\begin{array}{l}\text { Philosophical } \\
\text { Perspectives }\end{array}$ & Ontology & Epistemology & Implication for Research \\
\hline $\begin{array}{l}\text { Objectivism } \\
\text { and Realism }\end{array}$ & $\begin{array}{l}\text { Reality exists in terms } \\
\text { of properties and } \\
\text { relations between its } \\
\text { entities }\end{array}$ & $\begin{array}{l}\text { Learning is recreating a } \\
\text { correct representation such } \\
\text { properties and relations in } \\
\text { human mind }\end{array}$ & $\begin{array}{l}\text { The effectiveness of an } \\
\text { educational intervention can } \\
\text { be determined by objectively } \\
\text { assessing learners' mastery } \\
\text { of "knowledge” } \\
\text { demonstrated by a series of } \\
\text { pre-specified behaviors. }\end{array}$ \\
\hline $\begin{array}{l}\text { Idealism and } \\
\text { Rationalism }\end{array}$ & $\begin{array}{l}\text { Our mind shapes the } \\
\text { world as we perceive it. } \\
\text { Reality is a mental } \\
\text { representation. }\end{array}$ & $\begin{array}{l}\text { Knowledge is acquired } \\
\text { through intellectual and } \\
\text { deductive reasoning rather } \\
\text { than the sensory } \\
\text { experience. }\end{array}$ & $\begin{array}{l}\text { Educational research should } \\
\text { shift its focus from } \\
\text { examining the change of } \\
\text { learners' behavior to the } \\
\text { change of the mental } \\
\text { structure and organization in } \\
\text { learners' mind }\end{array}$ \\
\hline Relativism & $\begin{array}{l}\text { Absolute truth and } \\
\text { reality does not exist. } \\
\text { Meanings of } \\
\text { experiential or physical } \\
\text { events are constructed } \\
\text { within the relationship } \\
\text { between them. }\end{array}$ & $\begin{array}{l}\text { Truth and falsity are } \\
\text { relative to the observer and } \\
\text { its cultural context. } \\
\text { Knowledge is socially, } \\
\text { culturally and } \\
\text { experientially constructed, } \\
\text { local and specific to the } \\
\text { observer and the context. }\end{array}$ & $\begin{array}{l}\text { Research should be } \\
\text { conducted in naturalistic } \\
\text { settings without controlling } \\
\text { extraneous variables. It } \\
\text { should allow learners to } \\
\text { describe their experience and } \\
\text { construct their own reality. }\end{array}$ \\
\hline Pragmatism & $\begin{array}{l}\text { Truth and reality is } \\
\text { contemporary, } \\
\text { ever-changing and a } \\
\text { matter of degree, } \\
\text { determined by its real } \\
\text { effects and practical } \\
\text { consequences. }\end{array}$ & $\begin{array}{l}\text { Knowledge is essentially a } \\
\text { plan of action, and } \\
\text { proposes practical ends to } \\
\text { be attained. Pragmatism } \\
\text { emphasizes the genetic and } \\
\text { instrumental character of } \\
\text { knowledge. }\end{array}$ & $\begin{array}{l}\text { It offers researchers a } \\
\text { philosophical and } \\
\text { methodological middle } \\
\text { ground, allowing both } \\
\text { quantitative and qualitative } \\
\text { data collection and analysis } \\
\text { methods to be used to address } \\
\text { certain research questions. }\end{array}$ \\
\hline
\end{tabular}


2.5 Ontological and Epistemological Difference between Quantitative and Qualitative Research

The distinctions between conducting quantitative and qualitative research are apparent, including the definitions of scientific method, purpose of the studies, use of research findings, form of data collection and analysis. Most of those distinctions can be traced back to different ontological and epistemological beliefs that are held by educational researchers. Ontological difference between the two research methodologies, according to Johnson and Christensen (2012), is that quantitative research are conducted under the assumption of objectivity while qualitative research are operated under the assumption that reality is socially constructed (Guba \& Lincoln, 1989). Quantitative researchers believe the existence of a reality and such reality can be observed and measured, as "rational observers who look at the same phenomenon will basically agree on its existence and its characteristics" (Johnson \& Christensen, 2012). On the contrary, qualitative researchers deny such universal reality and endorse the idea that multiple realities exist, which are "apprehendable in the form of abstract mental constructions, which are experientially based, local and specific” (Guba \& Lincoln, 1994, as cited in Maxwell, 1998, p.73). In terms of epistemology, quantitative research is confirmatory and deductive in nature, as knowledge is justifiable by empirical confirmation of hypotheses; whereas qualitative research is generally exploratory and inductive in nature, as knowledge is generated or constructed by researchers through subjective and empathetic understanding, exploration and inspection (Johnson \& Christensen, 2012).

\section{Qualitative Methods for Educational Technology Research}

In opposition to the common belief, employment of qualitative perspectives and data collection methods have a long tradition in educational technology research and are gaining more and more attention from researchers in the field. According to Savenye and Robinson (2004), "research questions and methods that might once have been deemed unacceptable are gaining acceptability; studies using a variety of qualitative methods and based on alternate paradigms may now be published” (p. 1045). For example, studies on the use of educational media often include description of how media are used in classroom activities and how teachers or students feel about such use, with narrative data from both observation and interview. There are also more and more case studies and design-based studies published with detailed description of the process, context, attitude, social relations, and researchers' subjectivity. Savnye and Robinson (2004) provided the statistical data regarding such phenomenon: when they searched the ERIC database using key phrases educational technology and qualitative research for all the publication between 1980 and 2000, 100 publications were located. Among them, the majority of publications (90 in total) were published between the year 1990 and 2000, whereas almost half (46) were published in just the more recent 3 years.

Based on the extent of prevalence in literature, ethnography, case study and design-based research are selected for discussion in this section as the three major qualitative methods used in the field of educational technology research. Their key characteristics, potentials and limitations will be analyzed using examples from the publications in the field. 


\subsection{Ethnography}

Ethnography as defined by Denzin (1997) is a "form of inquiry and writing that produces descriptions and accounts about the ways of life of the writer and those written about” (p. xi). When conducting an ethnography research, researchers should observe a setting to gather data, and also get involved in the setting, interacting with different players in pursuit of the research agenda (Silverman, 1997). Ethnographic studies in educational technology are usually conducted using the participant observation technique, in which the classroom behaviors and discourses of students or teachers are recorded in the form of fieldnotes. Analysis is conducted soon after the observation with the purpose to identify patterns of behaviors, events or phenomena to investigate further in future observations.

In many occasions, researchers are directly involved in the instruction process working as instructors or facilitators. For example, Turner (2000) investigated the use of two-way interactive television in the City Colleges of Chicago as the instructor in a two-way televised classroom, and managed to gather massive amounts of data regarding students' experience and perception on distance education from various sources such as class assignment, classroom observation, end of course surveys and interviews with students. Sometimes researchers just choose to sit back and observe, and assume the role of a visitor or a guest in the classroom. One such example is a study conducted by Robinson (1994), who studied the use of televised news show in classroom by attending a middle-western middle school for one semester as a visitor. However, she did participate in classroom discussion for hours and engage in conversation with students, teachers and school administrators. The visitor's role allowed her to collect more observation data and produce rich and vivid narrations that were rarely seen in educational technology research. The following is an excerpt from her ethnography that describes her feelings when she entered the school on the first day:

Loud noises. Clanging lockers, music, laughter, shouts, giggles, wails, dropping books, shuffling feet. Bell. A hush, a new almost-silence. The ebb and flow of sounds in a school hallway, a pattern repeating itself ten times each day, noise advancing and retreating, doors opening and shutting along with mouths and minds, no doubt. (p. 2)

Another excerpt is the author's explanation on the social relations within the school based on a discourse analysis, which she concluded later in her study as the reason behind the under-use of the educational television program.

The principal explained to me that the real driving force behind schools is the "three Bs--buses, bread, and basketball, athletics, transportation, and lunch are the big three." This type of sloganism may not mean too much, but there is a kernel of truth in it. Schools operate at the pleasure of their school boards, and they must be responsive to the conservatism of the community or the limitations of financial problems. Innovations, such as the Whittle offer, are accepted for the equipment offer, not because they fit into the curricular goals of a school district such as this one. And television doesn't even start with a B. (p. 9) 
It is important to note that Robinson entered the field with a specific set of research questions regarding the use of TV in class and reactions from students, teachers and school, thus she focused her observation only in those aspects, and didn't record other categories of interactions within the classroom. In fact, the lack of in-depth ethnography has been a major criticism towards the ethnographic studies on educational technology as they were often conducted for a short period of time, such as once a week for a few hours. Researchers usually lack the resources to live in the field for extended period of time; and for researchers who are also instructors, observation and fieldnotes writing also have raised some ethical concerns since doing so would make an instructor less dedicated in teaching thus can potentially harm the welfare and interests of the participants (students in most cases).

\subsection{Case Study}

Case study can be considered as a special form of ethnography. Like ethnography, case study is also conducted in a naturalistic setting, with the extensive use of narrative data from observation, interview, transcripts and notes to create rich narrations of perceptions, attitudes, reactions, relations and environments. However, it differs from most ethnographies in that "case studies focus on one particular instance of educational experience and attempt to gain theoretical and professional insights from a full documentation of that instance" (Freebody, 2003, p. 81). Case studies, based on its purpose, are categorized into three types (Yin, 2003):

- Explanatory: explanatory case studies seek to define how and or why an experience took place with the purpose to suggest "clues to possible cause-and-effect relationships”. Cases are used to explain or elaborate on the presumed causal links in real-life interventions that are too complex for the survey or other basic research designs.

- Exploratory: exploratory case study is used to explore situations in which the intervention being evaluated has no clear, single set of outcomes. Field work and data collection can take place prior to the establishment of research questions; and research findings are often seen as the onset of other forms of educational research.

- Descriptive case study is used to develop a document that fully illuminates the intricacies of an experience, presenting answers to a series of questions based on descriptive theories.

Case study has been traditionally used in qualitative report to document and discuss the design and implementation of technological applications, but nowadays more and more case studies also got published as research articles in educational technology journals. According to Shulman (1996), the lack of impact of basic research findings on daily educational practice is the main reason behind such phenomenon; as the principles or maxims proposed by basic research are often too vague and too general to be of any practical use for a specific context. On the contrary, the uniqueness of a case and a researcher's subjective experience within that case can result in an in-depth exploration of a contextualized instance (or bounded system according to Creswell) based on extensive data collection and reflection in the case study. As a result, "case studies show a strong sense of time and place; they represent a commitment to 
the overwhelming significance of localized experience” (Freebody, 2003, p.81). According to Yin (2003), case study can be considered as an appropriate research method in the following conditions:

- The focus of the study is to answer "how" and "why" questions.

- Researchers cannot manipulate the behavior of participants.

- Contextual conditions are highly relevant to the phenomenon under study.

- The boundaries are not clear between the phenomenon and context.

One example of case study in educational technology research is a study that explored issues related to a distance learning course delivered via multimedia technologies (Luetkehans, 1999). Case study was employed as the research methodology because the uniqueness and complexity of the online learning context was regarded as highly relevant to the phenomenon under study. Data collected from surveys, observations, semi-structured interviews, computer transcripts, participant debriefings, and focus group interviews were used to offer readers an in-depth view on how the design features and implementation of computer and media technologies facilitated collaborative learning in such online learning environment.

Researchers' reflections on their experiences can also be an important source of data in case study, and can yield to useful findings for educators in similar contexts. For instance, Foley and Luo (2011) conducted a case study that used a single case of creating an educational iPhone app to explore the role of rapid prototyping in mobile-learning system design. A lot of their own reflections regarding the design and testing process of the iPhone app were included in their case study to address the benefits and limitations of their proposed technological solution and were constantly referred to during the discussion. A typical narration of such reflection is exemplified in the following excerpt:

... Because the prototype of iAdvocate should meet certain functionality and interface design requirements for iOS, we felt it was important to test the prototype on iOS devices, Because of this, traditional methods for constructing a prototype such as using flash cards were not an option; however, iOS development requires specific programming skills and tools, which instructional designers do not necessarily have. Our development plan involved contracting iOS development, and we did not have the budget for early and multiple iterations of the full iOS app... (p.379)

Case study, as a qualitative research method is not without limitations. However, the common critiques towards case study (e.g. lack of reliability and validity, inability to generalize, uncontrolled bias and subjectivities) are unfair and problematic in my opinion; as they are raised based the quantitative research standards. In fact, the contextualized focus and subjective reflection should be considered as the unique value and strength of case study. That being said, there are still some issues one should consider before deciding to conduct a case study. First, case study is susceptible to producing too much detailed data that get both researchers and readers swamped in and lose focus of the key issues in research. Second, case study is not the most "cost-effective" way of doing research, since collecting and analyzing 
large amount of in-depth data can be both expensive and time-consuming. Last, the complexity examined in a case is difficult to represent simply; as there are often several different ways to present the same set of issues, with only subtle difference in approach and emphasis, which makes the findings of case study difficult to summarize (Hodkinson \& Hodkinson, 2001).

\subsection{Design-Based Research}

Design-based research (DBR), as an emerging paradigm of inquiry that aims to generate more "usable knowledge" for the problem of practice (Design-Based Research Collective [DBRC], 2003), has gained more and more attention from researchers in recent years. DBR can be defined as“a systematic but flexible methodology aimed to improve educational practices through iterative analysis, design, development, and implementation, based on collaboration among researchers and practitioners in real-world settings, and leading to contextually-sensitive design principles and theories" (Wang \& Hannafin, 2005, p.6). Unlike the "realist" view of most quantitative research or the "relativist" view of most qualitative research, "pragmatism" is considered as the epistemological philosophy behind DBR. According to Menand (1997), the logic of inquiry of DBR includes the use of induction (or discovery of patterns), deduction (testing of theories and hypotheses), and abduction (uncovering and relying on the best of a set of explanations for understanding one's results).

In the field of educational technology, DBR is often used to address and solve practical educational problems through designing and enacting technology applications, with the purpose to extend and refine theories along such process. The process DBR is often considered as interactive, collaborative, iterative, flexible and contextual (DBRC, 2003; Wang \& Hannafin, 2005), with four important phases: 1) analysis of the problem; 2) development of the solution; 3) iterative cycle of testing and refinement; 4) reflection to produce/revise design theories (Reeves, 2006).

Although DBR sometimes uses numeric data and quantitative methods in its analysis, it is considered as primarily a qualitative research in this paper for three reasons. First, DBR by nature is a naturalistic inquiry, conducted in a natural setting and use theories to explain phenomenon in a local context. Second, DBR is more interested in documenting the design process using narrative data rather than identifying the causal relationship among quantified constructs. Third, the research findings of DBR are not to be generalized; because changes and adjustments are constantly made to the design process in reflection to the complexity of its unique context. DBR is more concerned with providing details and insiders' views on explaining issues such as how the design features or principles have worked or have not worked, how the innovation has been improved, and what kind of changes have been made, etc. Such characteristics can be found in many DBR literatures (see Herrington, 1997; Hoadley, 2005; Kafai, 2005; Klopfer \& Squire, 2008; Squire, 2005; for examples)

Examples of DBR are seen in both journal articles and dissertations. Jan Herrington (1997) employed DBR in her dissertation study to investigate the ways students learn from an interactive multimedia learning environment based on a situated learning model. The primary data collection methods were observation of preservice teachers' using the interactive 
multimedia program, and interviews with both the preservice teachers and their supervising teachers in schools. The analysis was conducted qualitatively, using the three step process (data reduction, data display, and conclusion drawing and verification) proposed by Miles and Huberman (1994). Interviews were extensively used in Herrington's study to allow participants to express their opinions, concerns and attitudes regarding their experience of using the technologies. The following is an interview excerpt from the study showing a teacher's perception of using computer-assisted assessment in class:

I do that when I work with the kids that I tutor with, I get them to explain the question, explain how they go about getting to there, explain how they did it and then what they thought of the question in the first place ... 'Oh I remember that that's an old one' [referring to one of the problems on the video]. 'I treat it like roman numerals' [one of the students on the video says 'Yes roman numerals'] ... But that wasn't the way you normally think of pencil and paper they weren't just doing it on paper, they were talking about it. It is not just a monotonous test. (p.247)

Another classic DBR study was conducted by Klopfer and Squire (2008) to explore the potential use of hand-held devices in constructing a learner-centered, interactive learning environment. In their study, Klopfer and Squire documented the design and development process of creating an "augmented reality educational game" called Environmental Detectives (ED). Various decisions made during the iterative process of ED development and assessment were described in the study with rich narratives from observations, learners' feedback, and designers' comments and reflection, which formed the basis for pedagogical, practical and technical implications proposed in the study.

Like case study, DBR is often criticized as a non-scientific research method by quantitative researchers. While such criticism might be disregarded by DBR researchers as DBR is epistemologically rooted in pragmatism; DBR as an emerging research paradigm still faces several challenges. First of all, there is no agreed set of criteria or standards to evaluate if a research study qualifies as DBR. For example, Herrington et al. (2007) suggest that DBR should have two or more iterative cycles of testing and refinement of solutions in practice, while Ma and Harmon's (2009) argued that DBR can have only one iterative cycle. DBR is also susceptible to excessive data collection and being over-methodologized, as Dede (2004) pointed out that in many DBR studies "only the five percent or so of the data collected were needed to induce the findings” (p. 7).

\section{Conclusion}

In the past three decades, educational technology researchers have embraced the qualitative research methods in their investigation and exploration of different aspects of educational technology; the focus of inquiry has shifted from the effect of technology integration to broader issues around it such as aspects of instructional settings, interactions and views of learners and teachers, politics or social-economic relations behind educational institutions, instructional design decisions and their situated rationale, etc. Qualitative methods such as ethnography, case study and design-based research have been employed to address those 
issues, resulting in an increased publication of qualitative studies and useful findings that are otherwise impossible to acquire from basic research.

However, unlike other fields such as sociology or anthropology which have a long tradition of carrying out qualitative research, what counts as a rigorous qualitative study is rather loosely defined in the field of educational technology. Although narrative data were widely used in many educational technology studies, they were sometimes collected and analyzed based on the realist assumption that true knowledge exists and can be measured by learners' performance. Technology applications were treated as "deliverers" or "interventions" of instruction (Clark, 1983; Jonassen, Campbell \& Davidson, 1994), and their "effectiveness” in instruction was still the focus of inquiry for many studies, resulting in research conclusions that aimed to generalize rather than describe or explore. In many studies, data were often collected from a short period of time (e.g. several time points over the semester), and identities of race, gender, class and culture of both students and teachers were rarely discussed.

Acknowledging such problem, the Association for Educational Communications and Technology (AECT) has proposed a set of criteria for conducting qualitative research in the field of educational technology, with the purpose to increase its rigor, validity and social relevance (DeVaney, 2000). The criteria recommend researchers to address the practical value of the proposed research problem so that it has theoretical value and currency. The criteria also suggest more attention be paid to the ontological and epistemological assumptions behind the selected methodology in order to eliminate any competing epistemologies or other assumptions that might invalidate the research claims. With more and more experienced researchers starting to realize its unique value and potential and young researchers being trained in its methodologies, I am confident that qualitative research will continue to contribute to the scholarship and practice of educational technology in the years to come.

\section{Acknowledgement}

I thank Professor Sari Knopp Biklen for her guidance during the writing of this paper, as well as her wonderful instruction in the course EDU 815, Advanced Seminar in Qualitative Research. I also thank all the students in that course for their intellectual inputs, which enhanced my understanding of qualitative inquiry and provide me with plenty of new ideas and perspectives for this paper.

\section{References}

Bednar, A. K., Cunningham, D. J., Duffy, T. M., \& Perry, J. D. (1995). Theory into practice: how do we link? In Instructional Technology: Past, Present, and Future, edited by G. J. Anglin, pp. 100-112. Englewood, CO: Libraries Unlimited, Inc.

Bourke, V. J. (1962). "Rationalism". In D. D. Runes (Ed.), Dictionary of philosophy. Totowa, NJ: Littlefield Adams, and Company.

Clark, R. E. (1983). Reconsidering research on learning from media, Review of Educational 
Research, 53(4), 445-459.

Cronbach, L. J. (1975). Beyond the two disciplines of scientific psychology. American Psychologist, 30, 116-126. http://dx.doi.org/10.1037/h0076829

Dede, C. (2004). If design-based research is the answer, what is the question? Journal of the Learning Sciences, 13(1), 105-114. http://dx.doi.org/10.1207/s15327809jls1301_5

Denzin, N. (1997). Interpretive ethnography: Ethnographic practices for the $21^{\text {st }}$ century. Thousand Oaks, CA: Sage Publications.

Design-Based Research Collective. (2003). Design based research: An emerging paradigm for educational inquiry. Educational Researcher, 32(1), 5-8. http://dx.doi.org/10.3102/0013189X032001005

DeVaney, A. (2000, February). What positions should educational technology researchers take in this brave new world of cyberspace? What should we address? Presented at the annual meeting of the Association for Educational Communications and Technology, Long Beach, CA.

Dewey, J. (1999). The Essential Dewey. Volume 2. Bloomington: Indiana University Press, 1999.

Ebel, R. L. (1967) Some Limitations of Basic Research in Education. Phi Delta Kappan, 49, 81-84.

Foley, A. \& Luo, H. (2011). Prototype Development in Mobile-Learning Design Research. In Proceedings of World Conference on Educational Multimedia, Hypermedia and Telecommunications 2011 (pp. 376-383). Chesapeake, VA: AACE.

Freebody, P. (2003). Qualitative Research in Education: Interaction and Practice. London: Sage Press.

Gray, L., Thomas, N., \& Lewis, L. (2010). Educational Technology in U.S. Public Schools: Fall 2008 (NCES 2010- 034). U.S. Department of Education, National Center for Education Statistics. Washington, DC: U.S. Government Printing Office.

Guba, E. G., \& Lincoln, Y. S. (1983). The epistemological and methodological bases of naturalistic inquiry. In G. Madaus, M. Scriven, \& D. L. Stufflebeam (Eds.). Evaluation Models and Conceptualizations. Boston: Kluwer-Nijhof. Reprinted and abridged from the Educational Communications and Technology Journal, (Winter, 1982) 31, 233-252.

Herrington, J. (1997). Authentic learning in interactive multimedia environments. Edith Cowan University, Perth.

Herrington, J., McKenney, S., Reeves, T. \& Oliver, R. (2007). Design-based research and doctoral students: Guidelines for preparing a dissertation proposal. In the Proceedings of the World Conference on Educational Multimedia, Hypermedia and Telecommunications2007 (pp. 4089-4097), Chesapeake, VA. 
Hoadley, C. (2005). Design-based research methods and theory building: A case study of research with SpeakEasy. Educational Technology, 45(1), 42-47.

Hodkinson, P., \& Hodkinson, H. (2001). The strengths and limitations of case study research. Paper presented to the Learning and skills development agency conference: Making an Impact on policy and practice. Cambridge 2001

James, W. (1907). Pragmatism: A New Name for some Old Ways of Thinking, Cambridge MA: Harvard University Press, 1975.

Januszewski, A., \& Molenda, M. (2008). Educational Technology: A Definition with Commentary. New York: Lawrence Erlbaum Associates.

Johnson, B., \& Christensen, L. (2012). Educational research: Quantitative, qualitative, and mixed approaches. Los Angeles, CA: SAGE publication.

Johnson, R. B., \& Onwuegbuzie, A. J. (2004). Mixed methods research: A research paradigm whose time has come. Educational Researcher, 33 (7), 14-26. http://dx.doi.org/10.3102/0013189X033007014

Jonassen, D. H. (1996). Computers in the Classroom: Mind tools for Critical Thinking. Englewood Cliffs, New Jersey: Prentice-Hall, Inc.

Jonassen, D. H., Campbell, J. P., \& Davidson, M. E. (1994). Learning with media: Restructuring the debate. Educational Technology Research and Development. (42)2, 31-40. http://dx.doi.org/10.1007/BF02299089

Kafai, Y. B. (2005). The classroom as "living laboratory": Design-based research for understanding, comparing, and evaluating learning science through design. Educational Technology, 45(1), 26-33.

Klopfer, E., \& Squire, K. (2008). Environmental Detectives: The development of an augmented reality platform for environmental simulations. Educational Technology Research and Development, 56(2), 203-228. http://dx.doi.org/10.1007/s11423-007-9037-6

Lakoff, G. (1987). Women, Fire, and Dangerous Things: What Categories Reveal About the Mind. Chicago, IL: The University of Chicago Press.

Lombardo, T. J. (1987). The Reciprocity of Perceive and Environment: The Evolution of James J. Gibson's Ecological Psychology. Hillsdale, NJ: Lawrence Erlbaum Associates.

Luetkehans, L. (1999, February). A case study of using groupware to support collaborative activities in a distance learning course. In Proceedings of selected research and development papers presented at the national convention of the Association for Educational Communications and Technology 1999 (pp. 491-502), Houston, TX.

Ma, Y., \& Harmon, S. (2009). A Case Study of Design-Based Research for Creating a Vision Prototype of a Technology-Based Innovative Learning Environment. Journal of Interactive Learning Research, 20(1), 75-93. 
Mackay, N. (1997). Constructivism and the logic of explanation. Journal of Constructivist Psychology, 10, 339-361. http://dx.doi.org/10.1080/10720539708404631

Maxwell, J. A. (1998). Designing a qualitative study. In Leonard Bickman \& Debra J. Rog (Eds.),Handbook of applied social research methods (pp.69-100). Thousand Oaks: Sage.

Menand, L. (1997). Pragmatism: A reader. New York: Vintage.

Miles, M.B., \& Huberman, A.M. (1994). Qualitative data analysis: An expanded sourcebook (2nd. ed.). Thousand Oaks, CA: Sage.

Reber, A. S. (1995). The Penguin Dictionary of Psychology. New York: Penguin Books.

Reeves, T. C. (1995). Questioning the questions of instructional technology research. In M. R. Simonson \& M. Anderson (Eds.), Proceedings of the Annual Conference of the Association for Educational Communications and Technology, Research and Theory Division1995 (pp. 459-470), Anaheim, CA.

Reeves, T.C. (2006). Design research from a technology perspective. In: van den Akker, J., Gravemeijer, K, McKenney, S. \& Nieveen, N. (Eds). (2006). Educational design research. London: Routledge, 52-66.

Robinson, R. S. (1994). Investigating Channel One: A case study report. In DeVaney, A. (Ed.), Watching Channel One. Albany, NY: SUNY Press.

Ross, S. M., Morrison, G. R., \& Lowther, D. L. (2010). Educational technology research past and present: Balancing rigor and relevance to impact school learning. Contemporary Educational Technology, 1, 17-35.

Savenye, W.C., \& Robinson, R.S. (2004). Qualitative research issues and methods: An introduction for educational technologists. In Jonassen, D.H. (2004). Handbook of Research on Educational Communications and Technology (pp.1045-1072). Mahwah, NJ: Erlbaum.

Silverman, D. (1997) Qualitative research. Theory, method and practice. London, England: Sage Publications.

Spector, J.M. (2001). An Overview of Progress and Problems in Educational Technology (1). Interactive Educational Multimedia, 27-37.

Squire, K. (2005). Resuscitating research in educational technology: Using game-based learning research as a lens for looking at design-based research. Educational Technology, 45(1), 8-14.

Turner, A. M. (2000). Voices of the people: Experiences with two-way interactive television in the City Colleges of Chicago. Unpublished doctoral dissertation, Northern Illinois University.

U.S. Department of Education, National Center for Education Statistics. (2010). Digest of Education Statistics, 2009 (NCES 2010-013), Chapter 2.

Wang, F., \& Hannafin, M. J. (2005). Design-based research and technology-enhanced 


\section{Macrothink}

International Journal of Education ISSN 1948-5476 2011, Vol. 3, No. 2: E13

learning environments. Educational Technology Research and Development, 53(4), 5-23. http://dx.doi.org/10.1007/BF02504682

Yin, R. K. (2003). Case study research: Design and methods (3rd edition). Thousand Oaks, CA: Sage.

Yolanda, E. (1998) Kant's Idealism. Journal of the history of philosophy, 36(1), 143-144.

\section{Copyright Disclaimer}

Copyright reserved by the author(s).

This article is an open-access article distributed under the terms and conditions of the Creative Commons Attribution license (http://creativecommons.org/licenses/by/3.0/). 